\title{
Tansy Oil
}

National Cancer Institute

\section{Source}

National Cancer Institute. Tansy Oil. NCI Thesaurus. Code C72202.

The essential oil extracted from Tanacetum vulg are plants. Tansy oil can be toxic but has been used in a dilute form as a treatment for expelling internal roundworms. 